\begin{tabular}{|} 
Ambiente \& Água - An Interdisciplinary Journal of Applied Science \\
ISSN 1980-993X - doi:10.4136/1980-993X \\
www.ambi-agua.net \\
E-mail: ambi.agua@gmail.com
\end{tabular}

\title{
Isozymes of malate-and lactate dehydrogenase of Astyanax bimaculatus as biomarkers of environmental impact
}

\author{
doi:10.4136/ambi-agua.2308
}

Received: 20 Nov. 2019; Accepted: 21 Dec. 2019

\begin{abstract}
Marilia Elias de Almeida ${ }^{1,2}$; Maria Tereza Oliveira Batista ${ }^{3}$; Gannabathula Sree Vani ${ }^{3}$; Mariana Feijó de Oliveira ${ }^{4}$; Edson Rodrigues ${ }^{3}$; Cecilia Nahomi Kawagoe Suda ${ }^{3,4 *}$

${ }^{1}$ Departamento de Biologia. Universidade de Taubaté (UNITAU), Av. Tiradentes, n 500, CEP: 12030-180, Taubaté, SP, Brazil. E-mail: mariliabiodmais@gmail.com

${ }^{2}$ Departamento de Enfermagem Materno-Infantil e Saúde Pública. Escola de Enfermagem de Ribeirão Preto. Universidade de São Paulo (USP), R. Prof. Hélio Lourenço, nº 3900, CEP: 14040-902, Ribeirão Preto, SP, Brazil. E-mail: mariliabiodmais@gmail.com

${ }^{3}$ Programa de Pós-graduação em Ciências Ambientais. Universidade de Taubaté (UNITAU), Rua Visconde do Rio Branco, n 210, CEP: 12020-240, Taubaté, SP, Brazil. E-mail: contato.maria.tereza@gmail.com, gannabathulasreevani@gmail.com, rodedson@gmail.com

${ }^{4}$ Instituto Básico de Biociências. Universidade de Taubaté (UNITAU), Av. Tiradentes, n 500, CEP: 12030-180, Taubaté, SP, Brazil. Email: marifeijo.bio@gmail.com

*Corresponding author. Email: cnksuda@hotmail.com
\end{abstract}

\begin{abstract}
The activity of certain isozymes may serve as biomarkers of specific physiological conditions of living organisms. The present work aimed to evaluate malate dehydrogenase $(\mathrm{MDH})$ and lactate dehydrogenase (LDH) isozymes from the hepatic, branchial and renal tissues of the fish Astyanax bimaculatus as biochemical markers of environmental changes in the Una River Basin (Taubaté, SP, Brazil). For this study, the specimens were collected in water bodies located in three sampling sites of the basin, called P1 (Itaim stream), P2 (a stream along the Remédios municipal road) and P3 (a small lake near the Dr. José Luiz Cembranelli municipal road). Physicochemical analysis of the water from these sites indicated that P1 was the less polluted site, P2 presented high levels of electrolytes in water, and P3 presented the worst water quality among the sampling sites. The isoenzymes were separated by native-PAGE and identified by their activity on the polyacrylamide gel. The results indicated that four isozymes of $\mathrm{MDH}$ occur in the liver of these fish, and the activities of $\mathrm{MDH}-1$ and $\mathrm{MDH}-4$ were detected only in fish from P2, suggesting that these isoforms have potential as biomarkers of the presence of high levels of electrolytes in water. In the kidney, MDH-1 was detected in fish from P2 and P3, but it was not detected in those from P1, suggesting that the presence of this isozyme may be a biomarker of low-quality water. The gill MDH and LDH isozyme profiles of all tissues examined showed some similarities between individuals from the three collection sites, indicating that they are not suitable as biomarkers of the environmental conditions of these sites.
\end{abstract}

Keywords: Astyanax bimaculatus, enzymes, lambari-do-rabo-amarelo, water pollution. 
Marilia Elias de Almeida et al.

\section{Isozimas de malato desidrogenase e de lactato desidrogenase de Astyanax bimaculatus como biomarcadoras do impacto ambiental}

\section{RESUMO}

A atividade de determinadas isozimas pode ser biomarcadora de condições fisiológicas específicas dos organismos. O presente trabalho teve como objetivo avaliar as isozimas de malato desidrogenase (MDH) e de lactato desidrogenase (LDH) provenientes dos tecidos hepático, branquial e renal do peixe Astyanax bimaculatus como marcadoras bioquímicas de mudanças ambientais na Bacia Hidrográfica do Rio Una (Taubaté, SP, Brasil). Para isso, os espécimes desse peixe foram coletados em corpos d'água localizados em três locais da bacia, denominados P1 (ribeirão Itaim), P2 (córrego à beira da Estrada Municipal de Remédios) e P3 (lagoa próxima à Estrada Municipal Dr. José Luiz Cembranelli). Análises físico-químicas da água desses três locais indicaram que P1 foi o local menos poluído, P2 apresentou altos níveis de eletrólitos e P3 apresentou a pior qualidade da água entre os três. As isoenzimas foram separadas por meio de eletroforese em condições não-desnaturantes e identificadas pela sua atividade no gel de poliacrilamida. Os resultados indicaram que ocorrem quatro isozimas de MDH no fígado, sendo que as atividades de MDH-1 e MDH-4 foram detectadas somente nos peixes originários de $\mathrm{P} 2$, sugerindo que essas isoformas apresentam potencial como biomarcadoras da presença de níveis elevados de eletrólitos na água. No rim, a atividade de MDH-1 não foi detectada em peixes de $\mathrm{P} 1$, mas esteve presente em peixes de $\mathrm{P} 2 \mathrm{e} \mathrm{P} 3$, sugerindo que a presença dessa isozima pode ser biomarcadora de águas de baixa qualidade. Os perfis de isozimas de $\mathrm{MDH}$ branquial e de $\mathrm{LDH}$ de todos os tecidos examinados apresentaram algumas semelhanças entre indivíduos provenientes dos três locais de coleta, indicando que não são adequados como biomarcadores das condições ambientais presentes nesses locais.

Palavras-chave: Astyanax bimaculatus, enzimas, lambari-do-rabo-amarelo, poluição da água.

\section{INTRODUCTION}

Isozymes, or enzyme isoforms, are gene products of different protein coding genes. Isozymes originate from multiple gene loci that encode structurally distinct polypeptide chains. Isoforms may catalyze the same reaction, but differ in molecular weight, their kinetics, substrate affinity, number of subunits and amino acid sequences, electrical charge, or electrophoretic mobility. Isozyme analysis can be performed with chemical separation of proteins by nondenaturing native polyacrylamide gel electrophoresis (native PAGE). Due to different electrophoretic mobilities of isozymes, different band patterns (zymograms) are obtained. The zymograms are visualized using an enzyme-specific staining mixture, which includes substrate, cofactor and oxidized salt (Al-Huqail and Abdelhaliem, 2015). Isozymes can reside in different cellular compartments and could have different functions (e.g., cytosolic versus mitochondrial forms of malate dehydrogenase or superoxide dismutase) (Storey, 2015).

Malate dehydrogenase (MDH) catalyzes the reversible oxidation of malate to oxaloacetate, reducing $\mathrm{NAD}^{+}$to NADH. Cytosolic $(\mathrm{cMDH})$ and mitochondrial $(\mathrm{mMDH}) \mathrm{MDH}$ are found in vertebrates and invertebrates. Both isozymes are produced in cytosol from distinct genes, but mMDH is subsequently exported to the mitochondrial matrix (Basaglia, 1989; Musrati et al., 1998). Mitochondrial MDH is a Krebs cycle enzyme, while the cytosolic isoform reduces oxaloacetate in the cytoplasm. Both isozymes participate in the malate-aspartate shuttle system, ensuring the exchange of reducing equivalents between the cytoplasm and the mitochondrial matrix. MDH is also involved in gluconeogenesis and lipogenesis (Nelson and Cox, 2014).

Rev. Ambient. Água vol. 7 (supplement) - Taubaté 2019 
Furthermore, three or six MDH isozymes were found in fish (De Luca et al., 1983; Monteiro et al., 1991; Farias and Almeida-Val, 1992).

Lactate dehydrogenase $(\mathrm{LDH})$ catalyzes the reversible reduction of pyruvate to lactate, oxidizing NADH to $\mathrm{NAD}^{+}$. $\mathrm{LDH}$ is the terminal enzyme of anaerobic glycolysis and contributes to continued ATP production by glycolysis because the reaction permits NAD ${ }^{+}$regeneration. Previously it was thought that the enzyme was present only in the cytoplasm, but now there is robust evidence that the enzyme is also found in the mitochondria $(\mathrm{mLDH})$. Lactate can be transferred to the mitochondrial matrix via a lactate transporter protein (MCT1) and oxidized there to pyruvate by $\mathrm{mLDH}$, which provides pyruvate to oxidative processes and to gluconeogenesis in the matrix (Storey, 2015; Meshcheryakova et al., 2016). LDH is composed of $\mathrm{A}$ and $\mathrm{B}$ subunits, that forms homo- or heterotetramers in fish and higher animals. Five isozymes of LDH have been found, but salmonids and other tetraploid fish species express 1416 isozymes. (Meshcheryakova et al., 2016). Amazon fish express 3 LDH isoforms (de Almeida-Val et al., 1990), and brain and eye tissues of A. bimaculatus express 4 isozymes (Toledo Filho et al., 1978).

Activity levels of isoforms can be modulated by the environmental conditions where fish live. In the ocular and muscular tissues of the carp Cirrhinus mrigala and in the cardiac tissue of another carp Labeo rohita, MDH isozymes showed different patterns of electrophoretic mobility when fish from different collection sites (non-wastewater and wastewater ponds) were compared, suggesting that pollutants can regulate the expression and/or activity of these isozymes (Manna and Chakraborty, 2012). In microalgae Porphyridium cruentum (red alga), Scenedesmus incrassatulus (green alga) and Trachydiscus minutus (yellow-green alga) cultured in medium with and without nitrogen $(\mathrm{N})$ or subsequently resupplied with $\mathrm{N}$ to the starved cells, the results showed different numbers of expressed and active MDH isozymes (Gigova and Ivanova, 2015). The number of MDH isozymes of leaves was also changed in maize cultivated under salt stress when compared with control plants (Eprintsev et al., 2011). The fingerlings of the fish Mugil cephalus can express two isozymes of MDH, but one of them disappears when the fish is exposed to a specific nickel concentration in water (Nagarjuna and Mohan, 2017). In humans, LDH isozymes named LDH4 and LDH5 are predominantly expressed by tumor tissues and have been proposed as a diagnostic marker for endometrial cancer (Galal and Meleis, 2016) or for refractory Mycoplasma pneumoniae pneumonia (Liu et al., 2018). Therefore, MDH and LDH isozymes' expression and activity have potential as biomarkers, and the aim of this work was to investigate the isozymes of both enzymes as candidate biomarkers of environmental change in the Una river basin, located in São Paulo state, Brazil. These enzymes were extracted from hepatic, branchial and renal tissues of the fish Astyanax bimaculatus, locally called lambari-do-rabo-amarelo, abundant in the Una river (Honorio and Martins, 2018).

\section{MATERIALS AND METHODS}

\subsection{Sample collection}

Specimens of A. bimaculatus were caught with a line and hook and/or fishing net (size 20) in the Una river basin between December 2013 and March 2014. Fish capture was authorized by the Ministry of Environment (SISBIO, No. 41097-1) and the Committee for Ethics in Animal Research of University of Taubate (CEUA/UNITAU No. 013/2013). The collection sites were localized in the municipality of Taubate (SP) at (1) Itaim stream (P1), on the property of Fazenda Piloto (an experimental farm) of the University of Taubaté (S 2301'38,3', W $\left.45^{\circ} 30^{\prime} 31,6^{\prime \prime}\right) ;(2)$ Remédios (P2), in a stream located along the municipal road Remédios (S $\left.23^{\circ} 03^{\prime} 26.4^{\prime \prime}, \mathrm{W} 45^{\circ} 30^{\prime} 2.5^{\prime \prime}\right)$ close to a field with rice cultivation; (3) Ipiranga (P3), in a small lake near a pasture for cattle and close to the municipal road Dr. José Luiz Cembranelli ( $\mathrm{S}$ $\left.23^{\circ} 01^{\prime} 49,44^{\prime \prime}, \mathrm{W} 45^{\circ} 30^{\prime} 16,7^{\prime \prime}\right)$. A map of the sampling sites was published in previous studies

Rev. Ambient. Água vol. 7 (supplement) - Taubaté 2019 
(Batista et al., 2014; Ribeiro et al., 2015). Fish were immediately anesthetized with $0.1 \%$ (w/v) benzocaine, killed by decapitation and dissected. Hepatic, branchial and renal tissues were stored at $-86^{\circ} \mathrm{C}$.

\subsection{Tissue homogenates}

The tissues were homogenized in a Potter-Elvehjen using $50 \mathrm{mM}$ Tris-HCl buffer ( $\mathrm{pH} 7.4$ ), in the proportion 1:5 (w/v) and then subcellular structures were disrupted by a sonic dismembrator (Model 100, Fisher Scientific). The homogenates were centrifuged at 14,000 x g (Eppendorf 5810R) for 10 minutes. Supernatants were used for electrophoresis.

\subsection{Protein quantification}

Total protein was determined by the Bradford method (1976) using bovine serum albumin (BSA) as a standard.

\subsection{Electrophoresis and activity staining}

Non-denaturing polyacrylamide gel electrophoresis (native PAGE) was carried out with $2.5 \%$ stacking gel and $7.0 \%$ separating gel, in a buffer containing $25 \mathrm{mM}$ Tris and $192 \mathrm{mM}$ glycine. After pre-running for $1 \mathrm{~h}$, a sample volume containing $10 \mu \mathrm{g}$ of tissue total protein and $10.0 \%$ glycerol was loaded onto staking gel and the electrophoretic run was performed at $100 \mathrm{~V}$ for $3.5 \mathrm{~h}$ at $4^{\circ} \mathrm{C}$ (Davis, 1964). The electrophoretic conditions used for branchial LDH and MDH were slightly different from the standard normally adopted in this procedure since $9.0 \%$ separating gel was used instead of $7 \%$, and the run time was $4 \mathrm{~h}$.

After electrophoresis, the activity of $\mathrm{MDH}$ was revealed by incubating polyacrylamide gel in $168 \mathrm{mM}$ Tris- $\mathrm{HCl}$ buffer $(\mathrm{pH} 7.9)$ containing $210 \mathrm{mM}$ L-malate, $300 \mu \mathrm{M} \mathrm{NAD}^{+}, 26 \mu \mathrm{M}$ nitroblue tetrazolium (NBT) and $86 \mu \mathrm{M}$ phenazine methosulfate (PMS). The gel was incubated in the dark at $37^{\circ} \mathrm{C}$ for at least $2 \mathrm{~h}$. For $\mathrm{LDH}$ detection, the composition of solution for gel incubation was the same, except that malate was substituted by $200 \mathrm{mM}$ lactate (Lin and Somero, 1995).

For the negative control, after electrophoresis, the gel was incubated with all reagents but without the substrate. No bands were detected, indicating that unspecific dehydrogenases did not contribute to band formation.

\section{RESULTS AND DISCUSSION}

The physicochemical analysis of the water of P1, P2 and P3 at the time of fish capture has already been published (Batista et al., 2014; Ribeiro et al., 2015). These data indicated that: (1) the less impacted site was P1; (2) the hardness was the highest and the conductivity of the P2 aquatic environment $\left(198.7 \mu \mathrm{S} \mathrm{cm}^{-1}\right)$ was 1.9 times higher than in $\mathrm{P} 1$, and 1.6 times higher than in P3, suggesting that P2 fish were exposed to high levels of electrolytes from an impacted environment (Cetesb, 2009); (3) P3 presented the highest values of chemical oxygen demand (COD), indicating abundance of organic matter in the water, and presented higher values of apparent color, turbidity, nitrate and nitrite among the three sampling sites. Further analysis of the waters indicated that P2 had higher levels of calcium, chloride, iron, manganese and magnesium in comparison with $\mathrm{P} 1$ and $\mathrm{P} 3$. These analyses also showed that the aluminum level and Escherichia coli contamination is higher in P3 than in P2 or P1 (Batista et al., see preceding paper in this journal).

Four isozymes of MDH were detected in livers of A. bimaculatus (Figure 1A). MDH-1 is the isozyme that first migrated toward the positively charged anode and its presence as a faint band was detected only in the fish from P2. These fish also expressed two other isoforms of

Rev. Ambient. Água vol. 7 (supplement) - Taubaté 2019 
MDH (MDH-2 and MDH-4), and the fish "e" also presented MDH-3. Fish from P1 presented activity of MDH-2 or MDH-3. In fish from P3, only MDH-2 was clearly detected in all of them. When total activity of liver MDHs measured by spectrophotometric methods was compared among fish collected at the three sites, no statistically significant difference was found (Ribeiro et al., 2015). Nevertheless, the present data indicated that hepatic MDH of the fish from P2 showed a distinct pattern of isozyme expression when compared with fish from P1 and P2. Therefore, for detection of environmental changes, the analysis of the isozyme expression of hepatic MDH could be more sensitive than measurements of enzyme total activity. The pattern of isozyme expression showed by fish from $\mathrm{P} 2$ has potential as a biomarker of environments containing high levels of electrolytes. Water from $\mathrm{P} 2$ presented the highest values of hardness at the time of fish capture (Batista et al., 2014), and further analysis indicated high levels of calcium and magnesium in its water when compared with P1 and P3 (Batista et al., see preceding paper in this journal). Because $\mathrm{P} 2$ was localized in an agricultural area used for rice and other cultures, liming may be the origin of these minerals. In fish, iono- and osmoregulatory mechanisms require an energy supply that is mainly obtained by carbohydrates metabolized by the liver (Tseng and Hwang, 2008). Therefore, the expressions of MDH-1 and MDH-4 that were clear for fish from P2 may be involved with energy production and/or gluconeogenesis in order to respond to increased energy requirement for survival in this environment.

In gills (Figure 1B), MDH-1 was detected as a faint band in fish from P1 (individual "d"), P2 ("e" and " $\mathrm{P}$ ") and P3 ("i"). All fish presented MDH-2 and MDH-3. MDH-4 was not detected in fish from P3 and in the individual "c" from P1. A band at the top of the gel could be observed in all wells, however this band may be protein aggregates containing MDH. Right below the top, MDH-5 was more clearly detected in fish from P1 ("c" and "d"), P2 ("e", "f" and "g") and P3 ("k"). Because some individuals from different sites showed similar patterns of isozyme expression ("c" and " $\mathrm{k}$ " or " $\mathrm{d}$ " and "e"), it can be concluded that environmental differences did not produce a clear distinctive pattern of gill isoenzyme expression.

In kidneys (Figure 1C), MDH-1 was detected as a faint band in all fish from P3 and in the individual "e" and "g" from P2. MDH-2 was present in almost all fish, except in fish "c" and "j" from P1 and P3, respectively. The fish "c" and "j" showed MDH-3 and only the fish "c" showed MDH-4. The most peculiar characteristic of MDH isozymes of kidney is the undetectable levels of MDH-1 in fish from P1. Therefore, the expression of MDH-1 may be related to environmental changes of $\mathrm{P} 2$ and $\mathrm{P} 3$, and the expression or activity of this isozyme was not required in the less impacted area (P1). However, two fish from P2 ("f" and " $h$ ") also did not show MDH-1, indicating that kidney MDH-1 expression is not a clear biomarker for environmental conditions of the sampling site P2. Nevertheless, de Almeida et al. (2016) found that $\mathrm{MDH}-1$ of muscle of $A$. bimaculutus from $\mathrm{P} 3$ increased about twice in comparison with $\mathrm{P} 1$ and $\mathrm{P} 2$. Therefore, muscle MDH-1 and kidney MDH-1 could be candidate biomarkers of environmental conditions at $\mathrm{P} 3$.

LDH-1 was the isozyme that first migrated toward the anode (Figure 2). Three isoforms of $\mathrm{LDH}$ were detected in livers of $A$. bimaculatus, and all fish from the three sampling sites presented LDH-1 (Figure 2A). The activity of LDH-3 was higher in fish "h" from P3 when compared with all other fish, except for fish "g" that showed LDH-1, -2 and -3 with similar staining intensity of the bands. Only LDH-1 was clearly detected in fish from P1 and in the fish "f" from P2. More fish from P1 were also analyzed and only LDH-1 was detected in their livers (results not shown). Therefore, it may be possible that high expressions of LDH-2 and -3 were not required for fish from P1 because of environmental conditions at this site, which was the least impacted among sampling sites. However, because one fish from P2 ("f") showed a similar band pattern to fish from P1, more investigations are necessary to confirm this hypothesis. 


\section{A Liver $\mathrm{MDH}$}

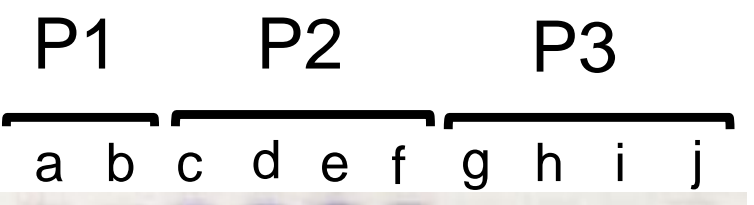

$\mathrm{MDH}-4=$

$\mathrm{MDH}-2-$

$\mathrm{MDH}-1-$

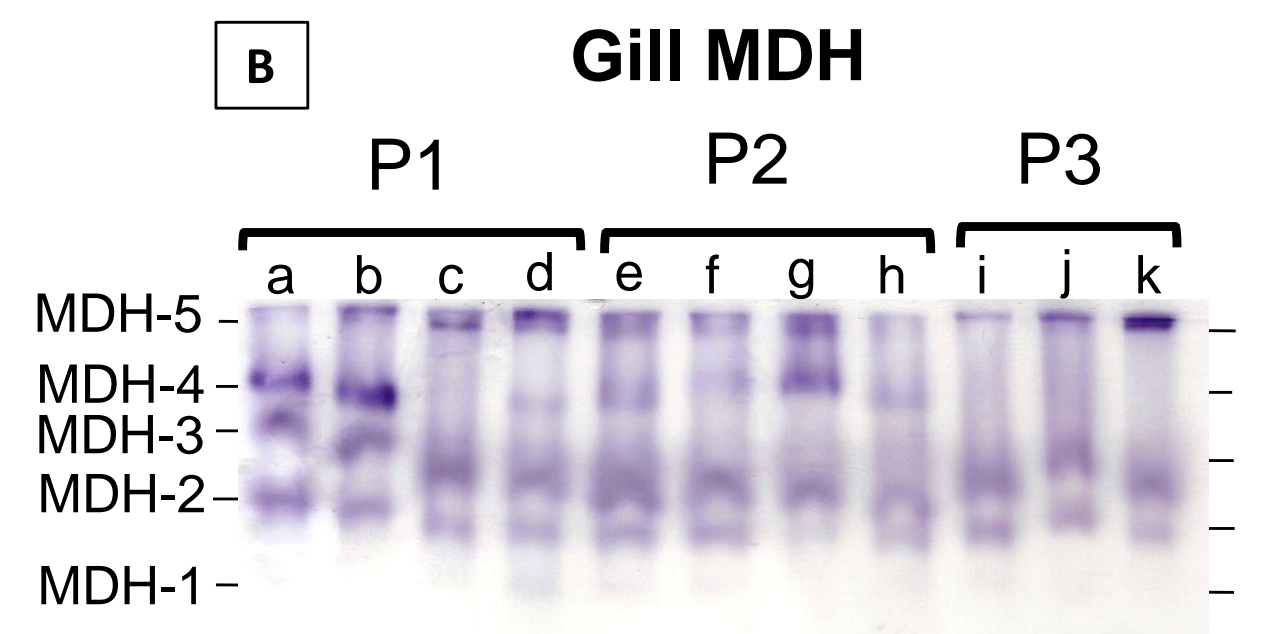

C Kidney MDH

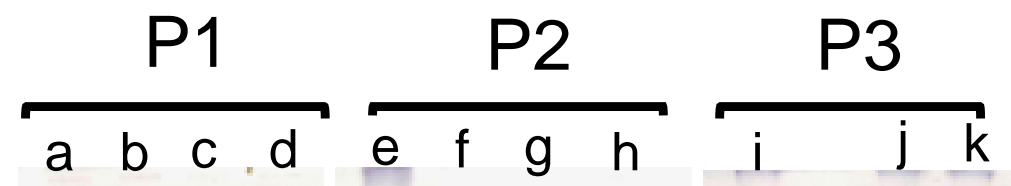

$\mathrm{MDH}-4$

$\mathrm{MDH}-3$ 二

$\mathrm{MDH}-2-$

$\mathrm{MDH}-1-$

Figure 1. Activity of MDH isozymes of different individuals (a-k) extracted from the liver, gills and kidney of $A$. bimaculatus collected at 3 sites (P1, P2 and P3). Equal letters (a-k) between liver, gill, and kidney trials do not necessarily indicate the same individuals. 

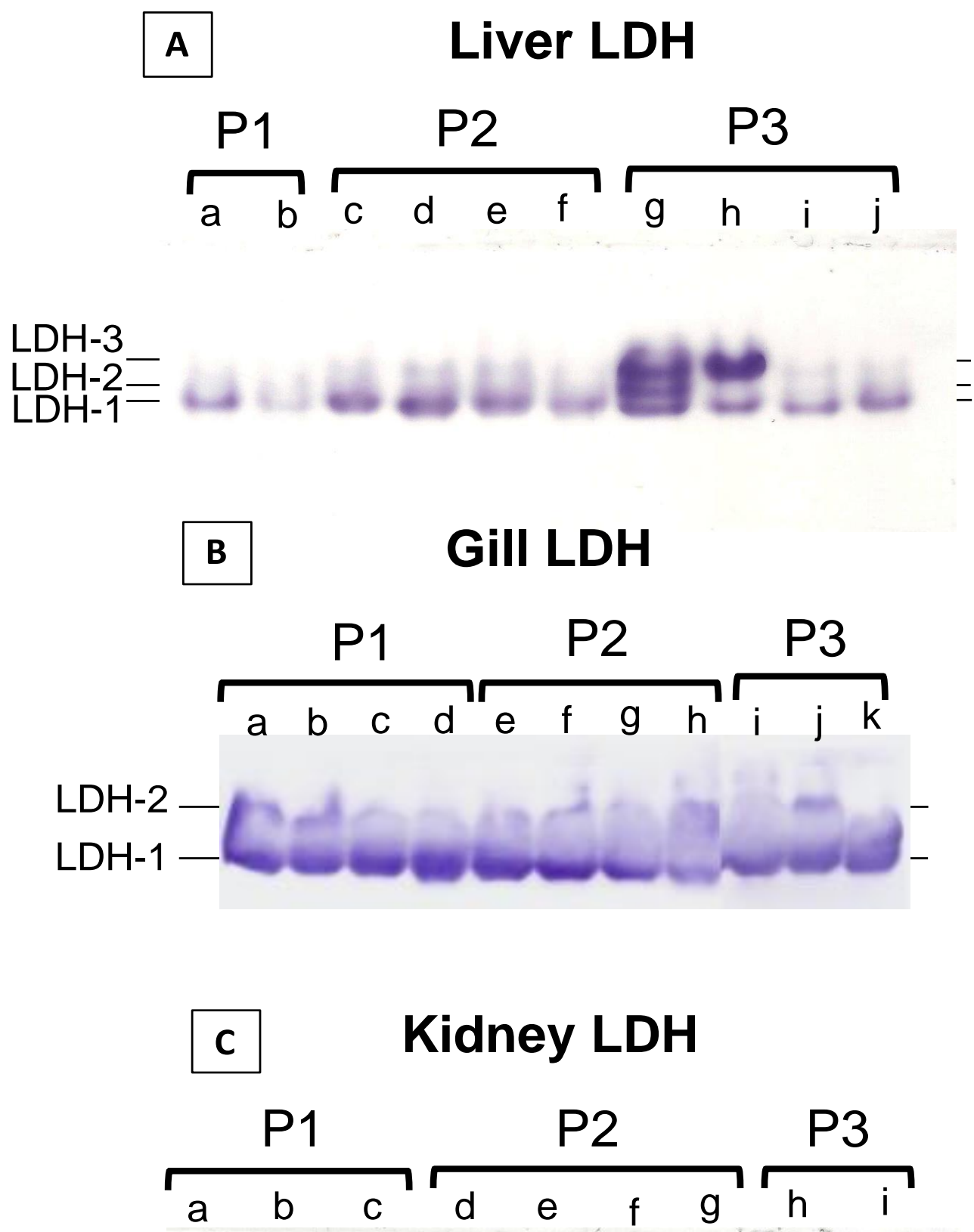

\section{$\mathrm{LDH}-1$}

Figure 2. Activity of LDH isozymes extracted from the liver, gills and kidney of different individuals (a-k) of A. bimaculatus collected at 3 sites (P1, P2 and P3). Equal letters (a-k) between liver, gill, and kidney trials do not necessarily indicate the same individuals.

Two isoforms of gill LDH were detected (Figure 2B). LDH-1 bands were more intensely stained than LDH-2 in all fish except for fish "h". Fish from different sampling sites showed similar staining patterns for the bands (e.g., "a", "b", "f" and " $\mathrm{j}$ "). Therefore, there are no clear and distinctive patterns of gill LDH isozyme activity in fish from the three sites. 
Only one LDH was detected in the kidney of A. bimaculatus, independent of sampling site (Figure 2C). In addition, total activity of LDHs of kidneys was not influenced by sampling site (Batista et al, see preceding paper in this journal). Hence, kidney LDH is not a suitable biomarker for prevailing environmental conditions at P1, P2 and P3.

Many factors affect LDH activity in fish, such as temperature and oxygen levels in water (Panepucci et al., 2000), starvation (Lowery and Somero, 1990), presence of metals in water (Reddy, 2012; Teodorescu et al., 2012) pesticides (Moreira et al., 2010) and herbicides (Xu et al., 2015). The activity of LDH isoforms can be regulated by rising levels of pyruvate that inhibit a specific isoform but does not affect other types of them. Enzyme acetylation, ubiquitination, SUMOylation, methylation and phosphorylation are mechanisms that regulate LDH in some organisms (Storey, 2015). Therefore, LDH is sensitive to various factors and several mechanisms control its activity. The level of total LDH activity or isozyme activities could be distinct among the fish living in the same body of water because they could be under different physiological conditions due to disease and starvation. Hence, in general, LDH isoforms of A. bimaculatus could be signals of energy metabolism changes in the tissue but may not always indicate a cause, and the enzyme is an unspecific biomarker, if analyzed alone without other analyses.

\section{CONCLUSIONS}

The simultaneous expression of MDH-1 and MDH-4 in the liver of A. bimaculatus has potential as a biomarker in freshwater environments containing high levels of electrolytes such as calcium and magnesium. The activity of MDH-1 of the kidney appears to be related to P3, the site that presented the worst water quality. MDH isozymes from gills, as well as LDH from liver, gills and kidneys did not show potential as biomarkers of specific environmental conditions that prevailed in the sampling sites of the Una River basin.

\section{ACKNOWLEDGMENTS}

Maria Tereza Oliveira Batista and Marilia Elias de Almeida received a research initiation scholarship PIBIC/CNPq, process numbers IBB_022_2015 and IBB_019_2016, respectively.

\section{REFERENCES}

AL-HUQAIL, A. A.; ABDELHALIEM, E. Evaluation of Genetic Variations in Maize Seedlings Exposed to Electric Field Based on Protein and DNA Markers. BioMed Research International, v. 2015, p. 15, 2015. http://dx.doi.org/10.1155/2015/874906

BASAGLIA, F. Some aspects of isozymes of lactate dehydrogenase, malate dehydrogenase and glucosephosphate isomerase in fish. Comparative biochemistry and physiology. B, Comparative biochemistry, v. 92, n. 2, p. 213-226, 1989. https://doi.org/10.1016/03050491(89)90269-1

BATISTA, M. T. O. et al. Tissue levels of the antioxidant enzymes superoxide dismutase and catalase in fish Astyanax bimaculatus from the Una River Basin. Revista Ambiente \& Água, Taubaté, v. 9, n. 4, p. 621-631, 2014. http://dx.doi.org/10.4136/ambi-agua.1473

BRADFORD, M. M. A rapid and sensitive method for the quantitation of microgram quantities of protein utilizing the principle of protein-dye binding. Analytical Biochemistry, v. 72, n. 1, p. 248-254, 1976. http://dx.doi.org/10.1016/0003-2697(76)90527-3 
CETESB. COMPANHIA AMBIENTAL DO ESTADO DE SÃO PAUlO. Apêndice A significado ambiental e sanitário das variáveis de qualidade das águas e dos sedimentos e metodologias analíticas e de amostragem. In: Qualidade das águas interiores no estado de São Paulo: Série Relatórios. Governo do Estado de São Paulo, Secretaria do Meio Ambiente. 2009. Available at: https://cetesb.sp.gov.br/aguas-interiores/publicacoes-erelatorios/ Access in: November 2019.

DAVIS, B. J. Disc electrophoresis - II Method and application to human serum proteins. Annals of the New York Academy of Sciences, v. 121, n. 2, p. 404-427, 1964. http://dx.doi.org/10.1111/j.1749-6632.1964.tb14213.x

de ALMEIDA, M. E. et al. Atividade da malato desidrogenase muscular de Astyanax bimaculatus da bacia hidrográfica do rio Una como biomarcadora de impacto ambiental. Revista Ambiente \& Água, v. 11, p. 1096-1108, 2016. http://dx.doi.org/10.4136/ambiagua. 1898

de ALMEIDA-VAL, V. M. F.; SCHWANTES, M. L. B.; VAL, A. L. LDH isozymes in amazon Fish-I. Electrophoretic studies on two species from serrasalmidae family: Mylossoma duriventris and Colossoma macropomum. Comparative Biochemistry and Physiology Part B: Comparative Biochemistry, v. 95, n. 1, p. 77-84, 1990. https://doi.org/10.1016/0305-0491(90)90251-N

DE LUCA, P. H.; SCHWANTES, M. L. B.; SCHWANTES, A. R. Adaptative features of ectothermic enzymes - IV. Studies on malate dehydrogenase of Astyanax fasciatus (Characidae) from lobo reservoir (São Carlos, São Paulo, Brasil). Comparative Biochemistry and Physiology Part B: Comparative Biochemistry, v. 74, n. 2, p. 315324, 1983. http://dx.doi.org/10.1016/0305-0491(83)90019-6

EPRINTSEV, A.; FEDORINA, O.; BESSMELTSEVA, Y. S. Response of the malate dehydrogenase system of maize mesophyll and bundle sheath to salt stress. Russian Journal of Plant Physiology, v. 58, n. 3, p. 448, 2011. https://doi.org/10.1134/S102144371102004X

FARIAS, I. P.; ALMEIDA-VAL, V. M. F. Malate dehydrogenase (sMDH) in Amazon cichlid fishes: evolutionary features. Comparative Biochemistry and Physiology Part B: Comparative Biochemistry, v. 103, n. 4, p. 939-943, 1992. http://dx.doi.org/10.1016/0305-0491(92)90219-H

GALAL, A. F.; MELEIS, M. Uterine fluid lactate dehydrogenase isoenzyme activity profile: can it be considered a diagnostic marker for endometrial cancer? Evidence Based Women's Health Journal, v. 6, n. 2, p. 42-46, 2016. https://doi.org/10.1097/01.EBX.0000481360.50934.8b

GIGOVA, L. G.; IVANOVA, N. J. Microalgae respond differently to nitrogen availability during culturing. Journal of biosciences, v. 40, n. 2, p. 365-374, 2015. https://doi.org/10.1007/s12038-015-9510-z

HONORIO, J. R.; MARTINS, I. A. Ichthyofauna of the Una river in the Paraíba do Sul Paulista River Valley, Southeastern of Brazil. Biota Neotropica, v. 18, n. 4, 2018. http://dx.doi.org/10.1590/10.1590/1676-0611-bn-2018-0528

LIN, J. J.; SOMERO, G. N. Temperature-dependent changes in expression of thermostable and thermolabile isozymes of cytosolic malate dehydrogenase in the eurythermal goby fish Gillichthys mirabilis. Physiological Zoology, v. 68, n. 1, p. 114-128, 1995. http://www.jstor.org/stable/30163921 
LIU, T.-Y. et al. Serum lactate dehydrogenase isoenzymes 4 plus 5 is a better biomarker than total lactate dehydrogenase for refractory Mycoplasma pneumoniae pneumonia in children. Pediatrics \& Neonatology, v. 59, n. 5, p. 501-506, 2018. https://doi.org/10.1016/j.pedneo.2017.12.008

LOWERY, M. S.; SOMERO, G. N. Starvation effects on protein synthesis in red and white muscle of the barred sand bass, Paralabrax nebulifer. Physiological Zoology, v. 63, n. 3, p. 630-648, 1990. https://doi.org/10.1086/physzool.63.3.30156233

MANNA, M.; CHAKRABORTY, P. Analysis of lactate and malate dehydrogenase enzyme profiles of selected major carps of wetland of Calcutta. Journal of Environmental Biology, v. 33, n. 4, p. 763-767, Jul 2012. https://www.researchgate.net/publication/235381406_Analysis_of_lactate_and_malate_d ehydrogenase_enzyme_profiles_of_selected_major_carps_of_wetland_of_Calcutta

MESHCHERYAKOVA, $O$. et al. Activities of cytochrome c oxidase and mitochondrial lactate dehydrogenase isozymes and $\operatorname{Cox} 1, \operatorname{Cox} 2, \operatorname{Cox} 4$, and Cox6 gene subunit expression in cold adaptation of Salmo trutta L. Russian Journal of Bioorganic Chemistry, v. 42, n. 2, p. 162-169, 2016. https://doi.org/10.1134/S1068162016010106

MONTEIRO, M. D. C.; SCHWANTES, M. L. B.; SCHWANTES, A. R. Malate dehydrogenase in subtropical fish belonging to the orders characiformes, siluriformes and perciformes I. Duplicate gene expression and polymorphism. Comparative Biochemistry and Physiology Part B: Comparative Biochemistry, v. 100, n. 2, p. 381-389, 1991. http://dx.doi.org/10.1016/0305-0491(91)90391-P

MOREIRA, S. et al. Ecotoxicological tools for the tropics: Sublethal assays with fish to evaluate edge-of-field pesticide runoff toxicity. Ecotoxicology and Environmental Safety, v. 73, n. 5, p. 893-899, 2010. https://doi.org/10.1016/j.ecoenv.2010.04.007

MUSRATI, R. A. et al. Malate dehydrogenase: distribution, function and properties. General Physiology and Biophysics, v. 17, n. 3, p. 193-210, 1998. http://www.gpb.sav.sk/1998/1998_03_193.pdf

NAGARJUNA, A.; MOHAN, D. Biochemical and histopathological changes induced by nickel in the striped mullet, Mugil cephalus (Linnaeus 1758). Bulletin of environmental

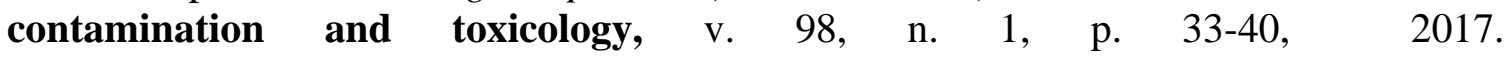
https://doi.org/10.1007/s00128-016-1961-x

NELSON, D., L; COX, M. Princípios de bioquímica de Lehninger. $6^{\text {a }}$ edição. Porto Alegre: Artmed Editora, 2014.

PANEPUCCI, L. et al. Changes in lactate dehydrogenase and malate dehydrogenase activities during hypoxia and after temperature acclimation in the armored fish, Rhinelepis strigosa (Siluriformes, Loricariidae). Revista Brasileira de Biologia, v. 60, n. 2, p. 353-360, 2000. http://dx.doi.org/10.1590/S0034-71082000000200021

REDDY, S. J. Impact of heavy metals on changes in metabolic biomarkers of carp fish, Cirrhinus mrigala. International Journal of Bioassays, v. 1, n. 12, p. 227-232, 2012. http://dx.doi.org/10.21746/ijbio.2012.12.0014

RIBEIRO, A. C. et al. Atividades de lactato desidrogenase e malato desidrogenase de Astyanax bimaculatus (lambari) da bacia hidrográfica do rio Una como biomarcadoras de impacto ambiental. Revista Ambiente \& Âgua, Taubaté, v. 10, n. 4, p. 793-803, 2015. http://dx.doi.org/10.4136/ambi-agua.1615 
STOREY, K. B. Comparative enzymology - new insights from studies of an "old" enzyme, lactate dehydrogenase. Comparative Biochemistry and Physiology Part B: $\begin{array}{llll}\text { Biochemistry and Molecular } & \text { Biology, }\end{array}$ http://dx.doi.org/10.1016/j.cbpb.2015.12.004

TEODORESCU, D. et al. Changes in lactate dehydrogenase activity in Carassius auratus gibelio (L. Pysces) kidney, gills and intestine induced by acute exposure to copper. Romanian Biotechnological Letters, v. 17, n. 6, p. 7873-7880, 2012. https://erepository.org/rbl/vol.17/iss.6/18.pdf

TOLEDO FILHO, S. A.; RIBEIRO, A. F.; FORESTI, F. Function of lactate-dehydrogenase C gene in Astyanax (Pisces, Characidae). Egyptian Journal of Genetics and Cytology, v. 7, n. 1, p. 52-55, 1978.

TSENG, Y.-C.; HWANG, P.-P. Some insights into energy metabolism for osmoregulation in fish. Comparative Biochemistry and Physiology Part C: Toxicology \& Pharmacology, v. 148, n. 4, p. 419-429, 2008/11/01/ 2008. https://doi.org/10.1016/j.cbpc.2008.04.009

XU, H.-D. et al. 1H NMR based metabolomics approach to study the toxic effects of herbicide butachlor on goldfish (Carassius auratus). Aquatic Toxicology, v. 159, p. 69-80, 2015. https://doi.org/10.1016/j.aquatox.2014.11.020 